\title{
Between Domestic and Public: Johann Leisentrit's (1527-1586) Instructions for the Sick and Dying of Upper Lusatia
}

\author{
Martin Christ
}

Dying in early-modern Europe was simultaneously domestic and public. As a growing body of work on public rituals of death emphasises, funerary processions, funeral sermons or bell ringing involved large numbers of people and in confessionally mixed areas they could constitute posthumous confessions of faith. ${ }^{2}$ Yet no matter what the chosen faith of a believer, devotion became a domestic, if not a private, matter once someone was bed-ridden. ${ }^{3}$ Sacraments and sacramentals associated with death had to be performed in a domestic context, and the final hours of a person's life were usually spent in their homes. ${ }^{4}$ For the clerical authorities, this setting could pose problems of regulation, as it was harder to control the domestic devotions of a dying man or woman than it was to test their faith in a church. It was with this in mind that clerical actors instructed their clergy on how to behave towards their flock in

1 I would like to thank Tom Hamilton, Jamie Page, Lyndal Roper, Carla Roth and the editors for their helpful comments. I am also grateful to the participants of the Domestic Devotions in the Early Modern World conference, the PRISMsox Early Modern Exchange and the Oxford Early Modern Workshop for their useful suggestions.

2 For example, Bärsch J., "Ordo Exsequiarum und 'ehrliches Begräbnis'. Eine vergleichende Analyse katholischer und protestantischer Begräbnisordnungen der frühen Neuzeit aus liturgiewissenschaftlicher Sicht", in Brademann J. - Thies K. (eds.), Liturgisches Handeln als Soziale Praxis. Kirchliche Rituale in der Frühen Neuzeit (Münster: 2014) 307-323; Koslofsky C.M., The Reformation of the Dead. Death and Ritual in Early Modern Germany, c.1450-1700 (Basingstoke: 1999); Hahn P., "The Reformation of the Soundscape: Bell ringing in Early Modern Lutheran Germany", German History 33, 4 (2015) 525-545. For English comparisons, see Cressy D., Birth, Marriage and Death. Ritual, Religion, and the Life-Cycle in Tudor and Stuart England (Oxford: 1999) 379-469; Tankard D., "The reformation of the deathbed in mid-sixteenth-century England", Mortality 8, 3 (2003) 251-267.

3 Karant-Nunn S., The Reformation of Feeling. Shaping the Religious Emotions in Early Modern Germany (Oxford: 2010) 189-215.

4 Exceptions include battles or prisoners condemned to death.

(C) MARTIN CHRIST, 2019 | DOI:10.1163/9789004375888_006

This is an open access chapter distributed under the terms of the prevailing CC-BY-NC-ND License at the time of publication. 
times of sickness. The suffering or delirium that the seriously ill endured was worrying to clerical authorities as it was possible for heretics to snatch away souls and condemn them to hell in such a weakened state.

Fear for the souls of the dying was so pronounced that in the West-Bohemian region of Upper Lusatia, a Catholic minority perceived persecution by the authorities that was far more dangerous in their imagination than the sources suggest it was in reality. The region of Upper Lusatia is located between Saxony, Bohemia and Brandenburg and, whilst belonging to different realms, there was never a territorial overlord who was solely responsible for the region and could enforce political and religious change. ${ }^{5}$ Bautzen was considered to be the capital of the region, as it was one of the largest and most prosperous towns. ${ }^{6}$ From $115^{8}$ to $15^{26}$, the region belonged to the kingdom of Bohemia and therefore to ever-changing dynasties. ${ }^{7}$ In 1526 , Lusatia became a Habsburg territory, before it came into the possession of Electoral Saxony in $1635 .{ }^{8}$ The Catholic Habsburg dynasty ensured that even if a town council decided to follow evangelical teachings it could not move decisively against Catholic actors. This royal protection resulted in constant negotiations between Lutheran town councils and the royally protected Catholic minority which found their focal point in three rural nunneries and the Catholic cathedral chapter in Bautzen.

Catholic domestic devotion was particularly emphasised by Johann Leisentrit, the dean (Domdekan) of Bautzen. Leisentrit was born in Olmütz in Moravia into an artisan's family in 1527 and then went on to study at the University of Krakow. ${ }^{9}$ In March 1549, Leisentrit was ordained as a priest. Subsequently, he became tutor at the court of arch-duke Ferdinand in Prague. In 1551 he was appointed canon of the collegiate church of St. Peter in Bautzen and in 1559 Leisentrit became dean and general commissioner for Upper and Lower Lusatia. In this position he oversaw the religious life of the whole of

5 For the Bohemian context, see also David Z.V., Finding the Middle Way. The Utraquists' Liberal Challenge to Rome and Luther (Washington, D.C. - Baltimore - London: 2003).

6 For the Lusatian League which Bautzen was part of, see Binder T. (ed.), 666 Jahre Sechsstädtebund (Görlitz - Zittau: 2012).

7 See also Bahlcke J., Regionalismus und Staatsintegration im Widerstreit. Die Länder der böhmischen Krone im ersten Jahrhundert der Habsburgerherrschaft (1526-1619) (Munich: 1994).

8 Fickenscher D., "Die Oberlausitzer Stände und ihre politischen Beziehungen zu Böhmen während der Habsburgherrschaft (1526-1618)", in Dannenberg L.-A. - Herrmann M. Klaffenböck A. (eds.), Böhmen-Oberlausitz-Tschechien. Aspekte einer Nachbarschaft (Görlitz Zittau: 2006) 81-108.

9 See Gülden J., Johann Leisentrits Pastoralliturgische Schriften (Leipzig: 1963); Seifert S., Johann Leisentrit 1527-1586 zum vierhundertsten Todestag (Leipzig: 1987). 
Lusatia. ${ }^{10}$ Leisentrit was not only responsible for the Catholic minority population of the region but also for any Lutherans. Although papal representatives offered Leisentrit more lucrative and comfortable positions on multiple occasions, he remained in Upper Lusatia where he administered a largely Lutheran region. He died in Bautzen in 1586. While the Catholics of Upper Lusatia enjoyed royal protection, their number was steadily decreasing in this period. Leisentrit feared that 'heretics' (Ketzer) would convert the few Catholics that survived in Upper Lusatia while they were weak and bed-ridden. He is a fascinating case study because he illustrates what a Catholic deemed to be the central tenets of a Catholic death and on which rites he was willing to compromise with the Lutherans.

Leisentrit displayed a contradictory and varied interpretation of Catholicism. His religious policies do not fit neatly into the category of CounterReformation Catholicism but neither did he renounce his Catholic beliefs. He maintained a mixed religious character and at times tolerated religious developments that were not in line with post-Tridentine Catholicism. He carried out baptisms in the German vernacular, for example, a practice normally associated with Lutheranism. He contributed to the confessional ambiguity of a region of the Empire that underwent a steady definition of orthodoxies, but never experienced a strong confessionalisation. ${ }^{11}$ Regulating domestic devotion was essential in warding off heretical threats for people like Leisentrit. Confessionally coded rituals, such as the singing of hymns in a domestic setting, have been studied in relation to persecuted minorities who sought to strengthen ties of kinship by participating in such actions. ${ }^{12}$ Huguenot peasants in France, for example, continued singing Reformed psalms at home. In Upper Lusatia, however, any such domestic devotion would have been of a confessionally mixed nature because Leisentrit's instructions on care for the dying included Lutheran elements, raising broader questions about how domestic devotion was performed and regulated..$^{13}$

10 Lower Lusatia never recognised Leisentrit's authority in the same way that Upper Lusatia did.

11 Bahlcke J. - Dudeck V. (eds.), Welt - Macht - Geist. Das Haus Habsburg und die Oberlausitz 1526-1635 (Görlitz: 2002); Bahlcke J. (ed.), Die Oberlausitz im frühneuzeitlichen Mitteleuropa. Beziehungen, Strukturen, Prozesse (Leipzig: 2007); Heimann H.-D. - Neitmann K. - Tresp U. (eds.), Die Nieder-und Oberlausitz - Konturen einer Integrationslandschaft, vol. 2: Frühe Neuzeit (Berlin: 2014).

12 Pollman J., "'Hey ho, let the cup go round!' Singing for reformation in the sixteenth century", in Schilling H. - Toth I.G. (eds.), Cultural Exchange in Early Modern Europe, vol. 1 (Cambridge: 2006) 294-316.

13 For a broader discussion of such confessional boundaries and their transgression, see Pietsch A. - Stollberg-Rilinger B. (eds.), Konfessionelle Ambiguität. Uneindeutigkeit und 
The example of Leisentrit provides new insights into the idea of dying a good death in a domestic setting. Upper Lusatia was a multi confessional region where it was possible for individuals to express their religiosity in idiosyncratic ways because there was no central religious power that unified belief systems. This also meant that Catholics like Leisentrit worried what went on behind closed doors and how men and women behaved in their homes. It has been argued that while Leisentrit acted irenically towards the Lutherans, his theology remained orthodoxly Catholic. ${ }^{14} \mathrm{~A}$ close analysis of his works shows, however, that although he wrote polemically against heretical sects, even in his theology of death he was willing to include Lutheran elements. For Leisentrit this was no contradiction because he knew that in order not to lose the few remaining Catholics in Upper Lusatia to Lutheranism, he needed to compromise and show some theological flexibility. Approaching Leisentrit's instructions on death by considering them in a domestic setting makes it possible to gain insights into the importance of domestic devotion, as well as illustrating the problems that authorities perceived with such practices.

In order to understand Leisentrit's instructions for the sick and dying, it is necessary to first discuss what an ideal Catholic or Lutheran deathbed looked like. ${ }^{15}$ In medieval Catholicism, ars moriendi instructed congregants on how to die a proper death, and their priests on the appropriate behaviour. ${ }^{16}$ This tradition started with works such as Anselm of Canterbury's Admonitio Morienti or Johannes Gerson's De arte moriendi (1400/1401). One type of ars moriendi also contained images depicting a pious death. ${ }^{17}$ These medieval illustrations show a dying person surrounded by saints and Jesus on one side and demons

Verstellung als religiöse Praxis in der Frühen Neuzeit (Heidelberg: 2013); Kaplan B.J., Divided by Faith. Religious Conflict and the Practice of Toleration in Early Modern Europe (Cambridge, MA - London: 2007).

14 Pavlickova R.P., "'Unter den Ketzern zu leben und zu sterben ist gar schwerlich und gefehrlich'. Das Sterbebuch des Johann Leisentritt im Kontext der katholischen Sterbebücher des 16. Jahrhunderts", Archiv für Reformationsgeschichte 107 (2016) 193-216.

15 For an Anglican deathbed, see Tankard, "The reformation of the deathbed".

16 Becker H. - Fugger D. - Pritzkat J. - Süß K. (eds.), Liturgie im Angesicht des Todes. Reformatorische und Katholische Traditionen der Neuzeit, vol. 2: Katholische Traditionen (Tübingen - and Basel: 2004); O'Connor M.C., The Art of dying well; the development of the Ars moriendi (New York: 1942).

17 See Resch C., Im Angesicht des Todes. Frühe reformatorische Anleitungen zur Seelsorge an Kranken und Sterbenden (Tübingen - Basel: 2006) 36-39; Crust L., The Master E.S. and 
on the other, symbolising a struggle for the soul of the dying person. ${ }^{18}$ The texts correspond to this idea that in order to reduce the time spent in purgatory, a dying person has to die a proper death. Once someone was bedridden, the family or friends of the sick person called on the priest, who processed through the town or village with the host and other liturgical equipment. Once the Catholic preacher had reached the house, his work consisted of three essential parts. First, confession with an absolution of sins, second a communion with the consecrated host and, finally, the extreme unction with blessed oil. Other sacramentals included the sprinkling of holy water onto the sick person, the kissing of a crucifix or the holding of a candle as a reminder of Christ's eternal light. While performing these rituals the priest or lay congregants could recite prayers, perform catechetical functions by asking the dying person about their belief or read Bible passages thereby calling them to penitence for their sins. ${ }^{19}$

After the Reformation, changes to these deathbed rituals were initially limited. In 1519, Martin Luther still retained penance, absolution and communion for the dying. ${ }^{20}$ Extreme unction was no longer an essential part of the last rites but could still be performed, and the apotropaic functions of holy water and the blessed candles were challenged. Later, Luther removed extreme unction from the last rites completely. ${ }^{21}$ But there were also significant local variations. In the church ordinance of electoral Brandenburg from 1540 , the procession to the dying person's house was retained, including a sexton who carried a lit candle. ${ }^{22}$ When Lutheran orthodoxies had been more clearly defined by the middle of the sixteenth century, last rites had been significantly simplified. Now, a Lutheran cleric would only provide confession and absolution and then give the dying person communion in both kinds. None of this process was considered to be a sacrament, unlike the Catholic last rites. Extreme unction, purgatory and the procession of the host were abandoned. Lutheran clerics developed their own version of ars moriendi which had a different emphasis

the 'Ars Moriendi'. A Chapter in the History of Engraving during the XVth Century (Oxford: 1898).

18 Crust, Master E.S. and the 'Ars Moriendi' 25-35.

19 Pavlickova, "Sterbebuch des Johann Leisentritt" 197-198.

20 Jordahn O., "Sterbebegleitung und Begräbnis bei Martin Luther", in Becker H. - Fugger D. Pritzkat J. - Süß K. (eds.), Liturgie im Angesicht des Todes. Reformatorische und katholische Traditionen der Neuzeit, vol. 1: Reformatorische Traditionen (Tübingen - Basel: 2004) 1-23.

21 Ibid.

22 Jordahn O., "Sterbebegleitung und Begräbnis in reformatorischen Kirchenordnungen", in Becker H. - Fugger D. - Pritzkat J. - Süß K. (eds.), Liturgie im Angesicht des Todes, Reformatorische und katholische Traditionen der Neuzeit, vol. 1: Reformatorische Traditionen (Tübingen - Basel: 2004) 23-6o, here 38 . 
to their Catholic counter-parts. Although Catholic ars moriendi also focused on Christ, this focus was even more pronounced in Lutheran deathbed manuals, where saintly intercession was replaced by a focus on Christ's redemption of sins. The cleric also provided solace (Trost). This emphasis was so strong that many of the Lutheran ars moriendi were called Trostbüchlein (solace booklets). ${ }^{23}$

\section{Leisentrit's Catholisch Pfarbuch}

Leisentrit's contribution to the genre of ars moriendi, his Catholic parish book (Catholisch Pfarbuch), displays a mix of Catholic and Lutheran elements. The book instructed men and women on how to behave in a domestic setting and was aimed primarily at Catholic clergy in Lusatia, but as the preface indicates, it could also be used by lay Catholics. ${ }^{24}$ The work was published in 1578 in Cologne and contains more than one hundred small tracts on all aspects of the rituals of dying, including the correct administration of the Eucharist and small catechisms to be performed before penance. The parish book only partly belongs to a Catholic tradition. Just as Reformed and Lutheran theologians adapted the genre of ars moriendi, Leisentrit, too, altered the genre to fit the specific conditions of Upper Lusatia. ${ }^{25}$ With clear and simple instructions, he addressed his priests who were supposed to hear confession, perform the Eucharist, give extreme unction and, while doing all this, comfort the sick and assure them of their Catholic belief. This makes it likely that he wanted his clergy to have this Catholisch Pfarrbuch with them in order to read prayers from it. ${ }^{26}$ There is a second edition from 1590, also printed in Cologne, which only contains two woodcuts, as opposed to the twenty-three contained in the first edition, and a short extract printed after $1648 .{ }^{27}$ Like most of Leisentrit's

23 For example, Spangenberg Johann, Ein new TrostBuechlin fur die Krancken Vnd Vom Christlichen Ritter (Wittenberg, Georgen Rhaw: 1548).

24 Leisentrit Johann, Catholisch Pfarbuch oder Form und Weise, wie die catholischen Seelsorger in Ober und Niderlausitz [...] ihre Krancken [...] besüchen [...] (Cologne, Maternus Cholinus: 1590). For the kinds of instructions, see, for example, 15-24. Throughout, images are taken from the 1578 edition and quotes from the 1590 edition.

25 For Lutheran and Reformed ars moriendi, see Flaeten J.O. - Rasmussen T. (eds.), Preparing for Death, Remembering the Dead (Göttingen: 2015).

26 For the British context of prayers in domestic settings, see Ryrie A., Being Protestant in Reformation Britain (Oxford: 2013), especially 363-409.

27 Anon.,SichersteStreitundSiegs-Kunstim Todteskampff [...]:Aus HerrnJohannLeisentrits [...] Catholischen Pfarrbuch [...] nachgedruckt (s.l., s.n.: after 1648). 
works, the Pfarbuch was primarily aimed at the Lusatian clergy, but there are indications that it also circulated in Silesia, Bohemia and other territories. ${ }^{28}$

The presence of multiple confessions in Upper Lusatia was clearly a concern for Leisentrit, who wanted to ensure that as many people as possible retained their Catholic faith. Most of the tracts in Leisentrit's parish book are written as a dialogue between the priest and the sick or dying person. The instructions retained central elements of Catholicism. In line with Catholic doctrine, Leisentritt stressed the importance of extreme unction, a recommendation he also repeated in other works. ${ }^{29}$ The priest was instructed to tell the sick person that it is a 'heiliges mittel' (holy remedy), instituted by Jesus, and to assure people of its salvific powers. Extreme unction is also depicted in a woodcut that is used in both Leisentrit's hymn book from 1567 and the parish book [Fig. 4.1]. In it, a priest is administering the sacrament with a man and a woman in attendance. It forms part of a depiction of the Seven Sacraments, making this woodcut distinctly Catholic. Leisentrit also recommended that dying people should hold a candle and that priests should sprinkle holy water onto the sick person. Unlike in Lutheran church ordinances, which cover all rituals surrounding death, Leisentrit did not mention the procession of the consecrated host and priest to the house of the dying person. For Catholic ars moriendi, however, it is not common to mention such a procession as they only focused on the domestic aspects of a person's death.

A woodcut from another of Leisentrit's works, his Catholic hymn book, illustrates both the Catholic rituals he wrote about and the centrality of domestic devotion for a dying person. ${ }^{30}$ Figure 4.2, taken from a section that interrogates the dying person's piety, shows a priest and a boy administering the last rites to a bed-ridden man. ${ }^{31}$ The scene is distinctly Catholic in nature, as the

28 Gerblich W., Johann Leisentrit und die Administratur des Bistums Meißen in den Lausitzen (Görlitz: 1931) 54.

29 Leisentritt Johann, Forma germanico idiomate baptisandi infantes, secundum catholicae veraeque apostolicae ecclesiae ritum [...] : nebst einer Kirchenordnung (Cologne, Maternus Cholinus: 1585) 38 .

30 Leisentrit Johann, Geistliche Lieder vnd Psalmen, der alten Apostolischer recht vnd warglaubiger Christlicher Kirchen [...] (Bautzen, Hans Wolrab: 1567). See also Heitmeyer E. - Wetzel R., Johann Leisentrit's Geistliche Lieder und Psalmen, 1567. Hymnody of the Counter-Reformation in Germany (Plymouth: 2014); Heitmeyer E., Das Gesangbuch von Johann Leisentrit 1567. Adaption als Merkmal von Struktur und Genese früher deutscher Gesangbuchlieder (St. Ottilien: 1988).

31 On the woodcuts in the hymn book, see Harasimowicz J., "Zur Ikonographie der Bautzener und Görlitzer Drucke im 16. und frühen 17. Jahrhundert", in Bahlcke - Dudeck (eds.), Welt-Macht-Geist 163-176; Lambert E., "Singing Together and Seeing Differently: Confessional Boundaries in the Illustrated Hymnal", in Dietz F. - Morton A. - Roggen L. - 


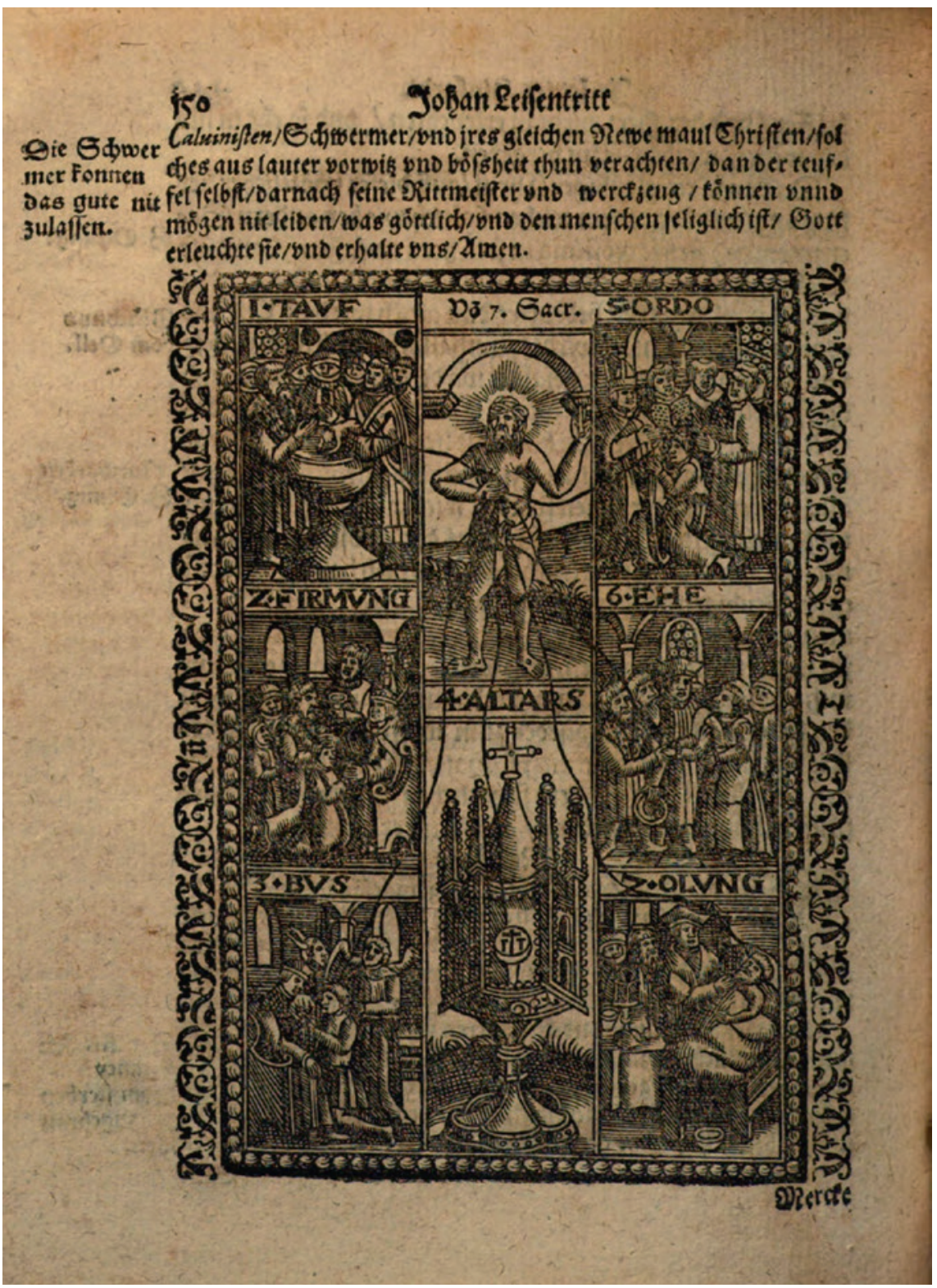

FIGURE 4.1 Unknown artist(s), "The seven Catholic sacraments", woodcut illustrations to Johan Leisentrit, Catholisch Pfarbuch oder Form und Weise, wie die catholischen Seelsorger in Ober und Niderlausitz [...] ihre Krancken [...] besüchen, [...] zur [...] Büß, und [...] entpfahung des Heiligen Sacrament des Altars [...] vermanen, [...] in todtes nöten [...] trösten; mit nachfolgung einer Catholischen Protestation wider alle Ketzereyen (Cologne, Maternus Cholinus: 1578), p. 150. Bayerische Staatsbibliothek, Munich, 4 Hom. 534\#Beibd.1 


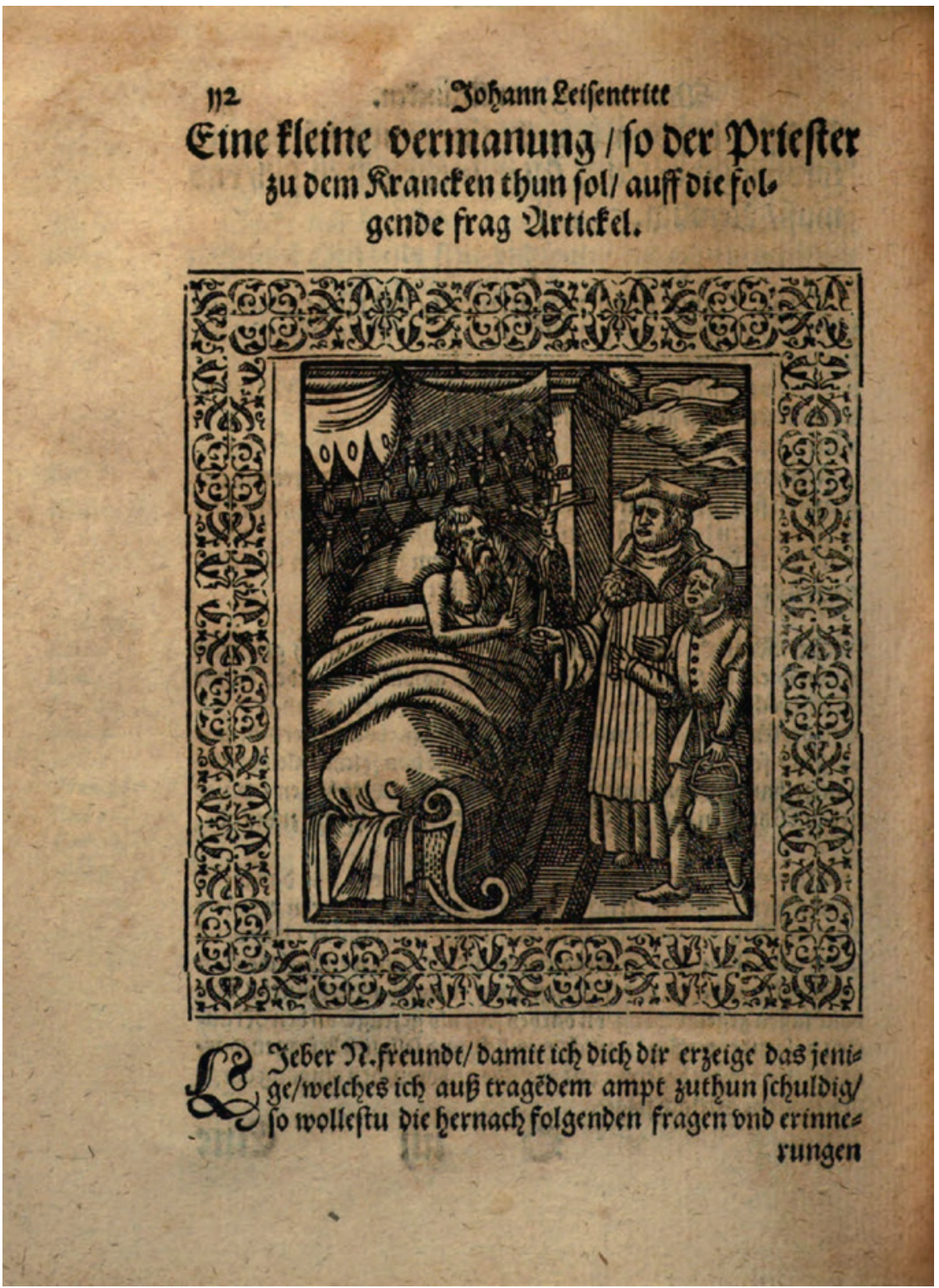

FIGURE 4.2 Unknown artist(s), "Administration of the Last rites by a priest", woodcut illustrations to Johan Leisentrit, Catholisch Pfarbuch oder Form und Weise, wie die catholischen Seelsorger in Ober und Niderlausitz [...] ihre Krancken [...] besüchen, [...] zur [...] Büß, und [...] entpfahung des Heiligen Sacrament des Altars [...] vermanen, [...] in todtes nöten [...] trösten; mit nachfolgung einer Catholischen Protestation wider alle Ketzereyen (Cologne, Maternus Cholinus: 1578), p. 112. Bayerische Staatsbibliothek, Munich, 4 Hom. 534\#Beibd.1 
boy is dispensing holy water with an aspergillum and the priest is holding up a crucifix which, according to Leisentrit, allowed the sick and dying to contemplate Christ's sacrifice for them. ${ }^{32}$ The sick man is holding up a candle in line with Catholic rituals, a common trope also in scenes of Mary's deathbed. ${ }^{33}$ According to Leisentrit, the candle served as a reminder of the light of Jesus who led everyone out of eternal darkness. ${ }^{34}$ What makes this woodcut particularly interesting as a scene of domestic devotion is that it is poised interestingly between interior and exterior ritual, as the wall of the sleeping chamber stops short of the priest, above whose head clouds suggest that he is outside and not quite part of the domestic scene. The priest in this image is located at the intersection of the two spaces, illustrating that the bedchamber of a dying person was a liminal space in multiple ways; between public and domestic, sacred and profane, inside and outside, life and death. In the bedchamber all these binary opposites overlapped, showing the many functions a bedchamber served.

In an environment in which Catholics could convert very easily to Lutheranism, Leisentrit not only stressed the salvific powers of Catholicism but also wanted his priests to be able to comfort their flock. He knew, as the images and texts demonstrate, that dying in the early modern world was frequently associated with pain and suffering. Most of the bed-ridden men in Leisentrit's woodcuts display haggard features, and some need a pillow to prop up their heads. Here, he seemed to be encouraging his priests to emphasise that this suffering was not meaningless. Interestingly, the priest was not needed for all the rituals surrounding death. After confession and the Eucharist, which had to be performed by a priest, a lay person could console the dying by telling them that God calls people from the 'Jammerthal' (vale of tears) of this life when he deems fit. The range of people to whom Leisentrit referred also illustrates that a variety of people could be present when a person was dying, diluting the boundary between public and private. In contrast to the written instructions, where friends and family feature, most of the woodcuts do not contain any outsiders and only depict the dying person and the priest, in one instance with a young helper. This might be explained by Leisentrit's insistence that some

Stronks E. - Vaeck M. van (eds.), Illustrated Religious Texts in the North of Europe, 15001800 (Farnham: 2014) 257-274. For a comparison of the woodcuts in the three editions, see Lipphardt W., Johann Leisentrits Gesangbuch von 1567 (Leipzig: 1964) 8-11.

32 Gülden, Leisentrit 151-154.

33 For the candle as a symbol of faith, see also Walsham A., "Domesticating the Reformation: Material Culture, Memory, and Confessional Identity in Early Modern England", Renaissance Quarterly 69 (2016) 566-616, here 594. 
rituals, such as the final confession, should be performed with only the dying person and a priest in the room.

The importance of all parts of the laity is illustrated when the fictitious priest addresses a sick woman. Normally the priest addresses the sick person as 'Lieber freundt' (dear male friend), but one tract starts with 'Lieber freundt (oder freundin)' (dear male (or female) friend). ${ }^{35}$ This salutation formula was also used in medieval ars moriendi. ${ }^{36}$ The priest (or lay person) was supposed to tell the dying person that it was God's plan to call them away from this evil world. Indeed, Leisentrit argued that the sooner someone dies, the happier they will be, because 'je lenger der Mensch lebet je mehrer und sehrer sein sünde' (the longer a human lives the more and greater are his or her sins). ${ }^{37} \mathrm{At}$ another point, Leisentrit explicitly included a range of people in his instructions and wrote that 'ein Catholischer mensch ehr sey ein Priester oder Leye Edell oder unedel Mans oder Weibs person' (a Catholic person, whether he is a priest or lay person, noble or not noble, man or woman) should avoid the temptations of the Devil and his heresies. ${ }^{38}$ In opposition to Reformed predestinarian theology, Leisentrit emphasized that the sick can make a choice between the Devil and God and therefore influence their own salvation. ${ }^{39}$

The laity's role in consoling the sick and dying, and the inclusion of a broad range of people in the instructions, show Leisentrit's concern for his flock. The less regulated nature of domestic devotion necessitated a greater level of involvement on the part of the laity and the increasing importance of Lutheranism in Upper Lusatia meant that Leisentrit had to find a balance between confirming believers' Catholicism and consoling them during their suffering. In one of his instructions he recommends that his priests say:

lieber freundt [...] erschrecke nicht für des todts angesicht ehr ist nicht halb bos als ehr erscheinet das sterben [ist wie zu] entschlafen [...] Christum Jesum unsern hern und Seligmacher ehr wirdt dir seine Göttliche handt reichen und aus dieser deiner letzten noth helfen

(my dear friend [...] do not be afraid of the face of death, he is not half as evil as he seems, death is only [...] like falling asleep, [...] Christ Jesus

35 Leisentrit, Pfarbuch 100.

36 Falk F., Die deutschen Sterbebüchlein von der ältesten Zeit des Buchdrucks bis zum Jahre 1520 (Cologne: 1890) 17.

37 Leisentrit, Pfarbuch 100.

38 Ibid. 141.

39 Karant-Nunn, Reformation of Feeling. 
our Lord and saviour will give you his divine hand and help you in your final need). ${ }^{40}$

As Susan Karant-Nunn has pointed out, Trost (solace) was particularly important amongst Lutherans. ${ }^{41}$ Leisentrit, too, referred frequently to the importance of solace, giving some of the tracts in his work a Lutheran colouring.

But in Leisentrit's detailed accounts, what he did not mention is also significant. Although he stressed the importance of saints in other works, in the last dying words of the repentant sinner, there was no saintly intercession involved but just a prayer directed at Jesus. Similarly, when Leisentrit mentioned saintly intervention in relation to death and sickness in his Pfarbuch, he devoted only one page to the subject. ${ }^{42}$ Other Catholic ars moriendi from the later sixteenth century contain frequent references to saints. In Adam Walasser's Kunst wohl $z u$ sterben (Art of dying well) from 1569, a whole chapter is dedicated to saints and their deaths. ${ }^{43}$ The focus on Jesus, rather than saintly intercession, also finds its visual equivalent in a woodcut of Jesus on the cross without Mary or any other saints surrounding him in the section on comforting those condemned to death in Leisentrit's Catholisch Pfarbuch [Fig. 4.3]. ${ }^{44}$ This is one of the rare occasions where the priest was instructed on how to use an image. The priest was supposed to say: 'Schaw an dises bilt welches in sich heldet und dir bedeutet das Jesus Christus [...] vor dich gestorben' (Look at this image which contains in itself and signifies to you that Jesus Christ [...] died for you). ${ }^{45}$ The absence of saints and angels from most of the woodcuts is a notable difference to the illustrations in medieval Catholic ars moriendi. ${ }^{46}$ There is also no reference to the Catholic practice of kissing the crucifix or purgatory. Although Leisentrit mentioned hell, he does not put the same emphasis as contemporary Catholic ars moriendi writers on purgatory. In Adam Walasser's work, for example, part of the instructions were dedicated to an explanation of purgatory,

$40 \quad$ Leisentrit, Pfarbuch 101.

41 Karant-Nunn, Reformation of Feeling.

42 Leisentrit, Pfarbuch 55 .

43 Adam Walasser, Kunst wol zusterben : Ein gar nutzliches Hochnothwendiges Büchlein auß heyliger Schrifft vnnd alten bewehrten Lehrern, mit sonderm fleiß gezogen, vnd mit schönen Exempeln vnd Figurn gezieret (Dillingen, Mayer: 1597) 255-270.

44 Leisentrit, Pfarbuch 173.

45 Ibid. 173.

46 For the reinterpretation of angels in Reformation England, see Marshall P., "Angels around the Deathbed: variations on a theme in the English art of dying", in Marshall P. - Walsham A. (eds.), Angels in the Modern World (Cambridge: 2006) 83-104. 


\section{Derurtheilte?}

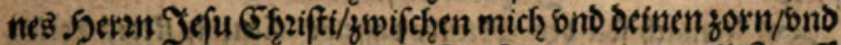
in beine bende befiele tich meinen geift/oenien bu wolleft auf

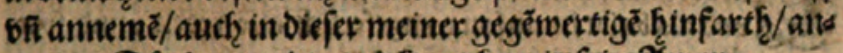
armen Sunder gnedig ond barmbersig fein. Ximen.

28 ann aber nbun ber arme finber foll ausge furet/ bno revegen feinet miffethabe/an leib vno leben geftrafft bno gericheet soerben,

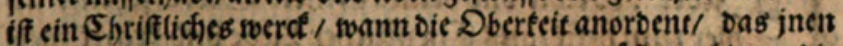
ber Priefer mit offentlichen permanung ond tróftung bis an bie fabet oss geridets thut beleiten/ Darumb bno atsbalot ber Sendet

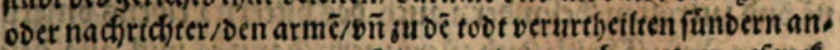
greiffen/imbie fenbe binden/fölgendts (nen audj aus bem gefend. nils furen nvill/ loll ber Wrieffer gegenwertig fein/ e ein Erucifix. in b.r hastot haben/ ober in vorker tragen lafien/ 66 Dem/ armen

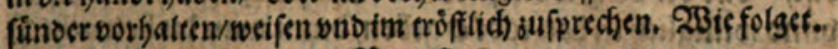

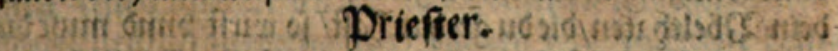

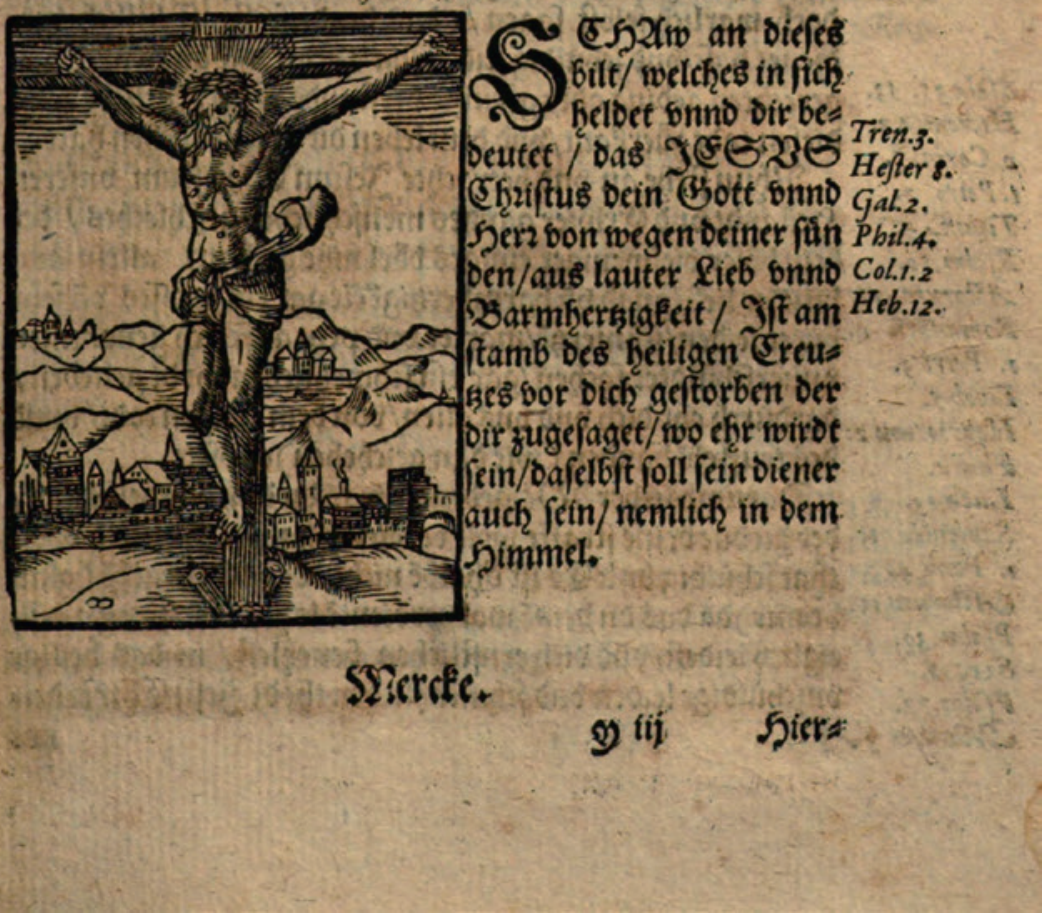

FIGURE 4.3 Unknown artist(s), "Christ on the cross", woodcut illustrations to Johan Leisentrit, Catholisch Pfarbuch oder Form und Weise, wie die catholischen Seelsorger in Ober und Niderlausitz [...] ihre Krancken [...] besüchen, [...] zur [...] Büß, und [...] entpfahung des Heiligen Sacrament des Altars [...] vermanen, [...] in todtes nöten [...] trösten; mit nachfolgung einer Catholischen Protestation wider alle Ketzereyen (Cologne, Maternus Cholinus: 1578), p. 173. Bayerische Staatsbibliothek, Munich, 4 Hom. 534\#Beibd.1 
including a woodcut showing angels pulling souls out of purgatory. ${ }^{47}$ Nothing of the kind can be found in Leisentrit's instructions.

\section{$4 \quad$ Imagining Challenges to a Catholic Death}

There is no indication that Catholics in Upper Lusatia were seriously persecuted and most conflicts occurred on a relatively small scale and with little violence. ${ }^{48}$ Such attacks include the burning of two papal effigies in Bautzen in the early Reformation years, a congregation chasing away a monk with faeces and stones, and complaints that Catholic sermons took too long. But Leisentrit invoked a narrative of persecution in his works. ${ }^{49} \mathrm{He}$ wrote that a great contempt, blasphemy and back-handed, dangerous persecution against Catholics has grown in the region and is now out of control. ${ }^{50}$ In Leisentrit's mind, the heretics have invited the Devil to take good Catholic souls to hell. In line with early modern theology, the Devil is seen as an opponent of God and the righteous believers: 'Wo der Sathan spreche [...] furchtet dich gar nicht dan[n] Gott verlast dich nicht' (Where Satan speaks [...] do not be afraid because God will not leave you). ${ }^{51}$ Leisentrit visualised these devilish temptations in one of the woodcuts in his Catholisch Pfarbuch which shows a sick man surrounded by three devils [Fig. 4.4]. It seems that this man is an example of someone who has turned away from his Catholic faith, as there is no priest nearby and no Catholic objects are visible in the scene. ${ }^{52}$

One particularly telling part of the Pfarbuch describes how a priest should behave towards 'Catholischen menschen mans unnd weibs personen so unter den ketzern sollen unnd müssen wonhafftig sein unnd bleiben' (Catholic people, men and women who have to live and remain amongst the heretics). ${ }^{53}$ According to Leisentrit, dying as a Catholic amongst heretics brought considerable risks with it. ${ }^{54} \mathrm{He}$ wrote that he has known many people who suffered

47 Walasser, Kunst wol zusterben 864.

48 For the Reformation context, see Speer C., "Die Reformation in der Oberlausitz. Ein Überblick", in Speer C. - Napp Th. (eds.), Musik und Konfessionskulturen 7-13; Blaschke K., Beiträge zur Geschichte der Oberlausitz (Görlitz - Zittau: 2000) 66-87.

49 Dittrich P., Die Meissener Diözese unter der Kirchenpolitik des 16. und 17. Jahrhunderts (Bautzen: 1960) 37-46.

50 Leisentrit, Geistliche Lieder 10.

$5^{1} \quad$ Leisentrit, Pfarbuch 114.

52 Ibid. 120.

53 Ibid. 139.

54 For this polemical dimension of Leisentrit's work, see also Pavlickova, "Sterbebuch des Johann Leisentritt". 


\section{0 Tohann Reifentrite Folget bott ekclichen onterweifingen/ rwie oie Siranten ferbenten S2ienfichen / Den STannigfeldtigen taufentiffigen anfecb) tunyeu - eรEatbang begegnen/in benfelbž/ourcb) (Sotto

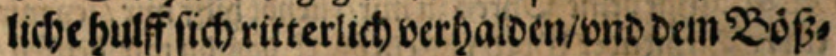 suidbt beftenoiglichen wiederpprect)en fol.}

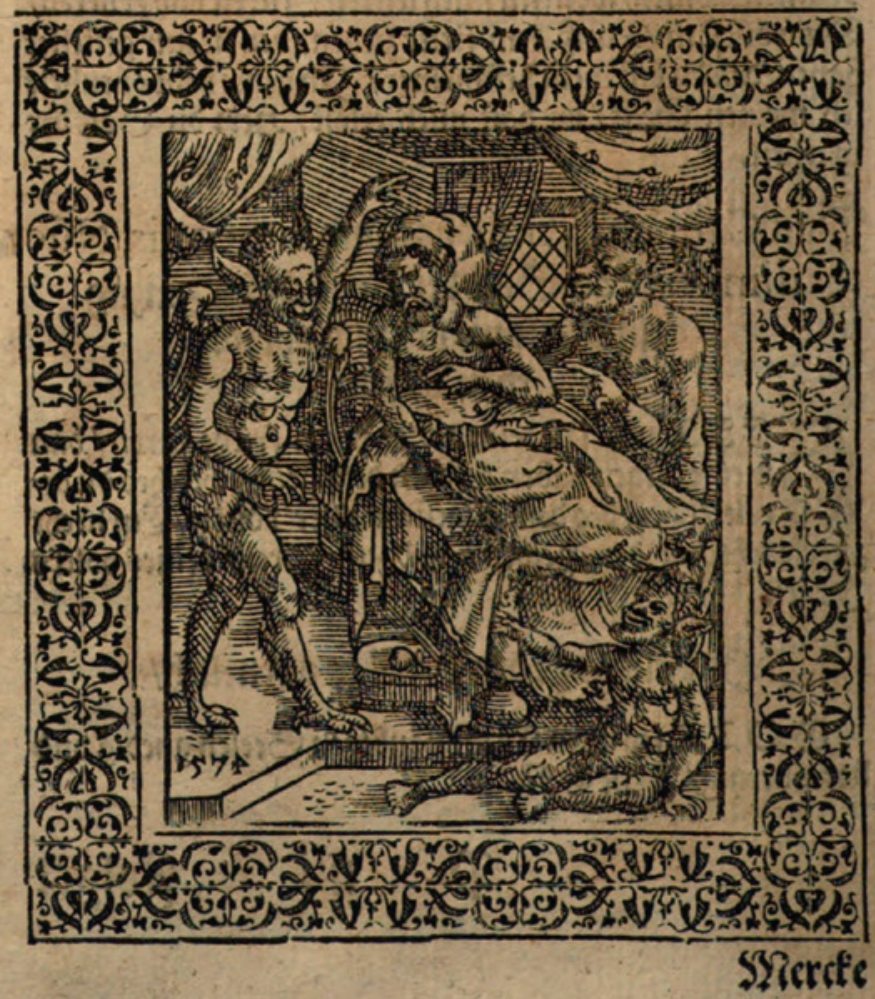

FIGURE 4.4 Unknown artist(s), "Dying man surrounded by three devils", woodcut illustrations to Johan Leisentrit, Catholisch Pfarbuch oder Form und Weise, wie die catholischen Seelsorger in Ober und Niderlausitz [...] ihre Krancken [...] besüchen, [...] zur [...] Büß, und [...] entpfahung des Heiligen Sacrament des Altars [...] vermanen, [...] in todtes nöten [...] trösten; mit nachfolgung einer Catholischen Protestation wider alle Ketzereyen (Cologne, Maternus Cholinus: 1578), p. 120. Bayerische Staatsbibliothek, Munich, 4 Hom. 534\#Beibd.1 
persecution and ridicule for their faith, yet remained steadfast until death and continued in their Catholic beliefs regardless of such taunts. However, there were also those who suffer heavily and because of the great pain in his body, the sick man 'nicht weis was er thut als dann kommet erst der teuffel unnd sein werckzeugk (ich meine die auffruischen ketzerischen Clamanten)' (does not know what he does and so the Devil comes first and then his tools [I mean the rebellious heretical Clamanten]). ${ }^{55}$ Leisentrit, for all his rhetoric of despicable heresies, therefore expected confessionally mixed groups to assemble around the deathbed. Within this heterogeneous setting, one might expect that Leisentrit also instructed his priests on how to convert Lutherans. The church ordinance of Brandenburg (1540) which specifically bans monks from attending to dying people shows that in other regions this was considered to be a problem. ${ }^{56}$ Leisentrit, however, did not comment on such conversions, suggesting a lack of confidence on his part.

He conjured up a scene in which the heretics tempt the sick and dying 'mit sehr heuchlischen und schmeichlischen worten' (with very duplicitous and flattering words) ${ }^{57}$ Leisentrit illustrated this point with the saying by Cato 'fistula dulce canit' which he then translated into German: 'Ein süsse Pfeiff der Vogler hat' (the bird catcher has a sweet whistle). But as if this explanation were not sufficient, he had to spell out 'Das er die Vögel bringt zum todt' (So that he can bring death to the birds). ${ }^{58}$ At other points, Leisentrit has translated whole tracts which were previously only available in Latin. ${ }^{59}$ So while Leisentrit saw his primary audience as one of educated Catholic priests, he also wanted to ensure that they were in a position to explain doctrine and heresies to the sick and dying in the vernacular. ${ }^{60}$ It is likely that he also wanted lay congregants to read these German tracts. The many small tracts and woodcuts suitable for private contemplation suggest that the parish book could also be used for personal devotion.

Leisentrit prepared the dying for even greater perils. If a Catholic maintained his beliefs regardless of all temptations, the 'teuffel unnd sein mutter' (Devil and his mother) will tell the dying that:

Als balt du Papistisch stürbest will ich vorbitten das man dir nit soll leuten dich auch nicht ehrlich sondern wie ein unvernünfftiges thier

55 Leisentrit, Pfarbuch 140.

$5^{6}$ Jordahn, "Sterbebegleitung und Begräbnis bei Martin Luther" 26.

57 Leisentrit, Pfarbuch 140.

58 Ibid. 140.

59 Ibid. 202.

6o See also Gülden, Leisentrit. 
ausschleppen dich auff den Schindt Anger legen unnd begraben lassen etc.

(if you [the sick] die as a Papist I will forbid that [bells] are rung [and you are buried] like a human and not honourably but take you outside like a wild animal, and put you on the village green to be buried there etc.). ${ }^{61}$

This episode illustrates how the act of dying linked the domestic and the public spheres. Although a person died in their private house and could receive penance, communion and extreme unction according to a certain religious tradition, when the deceased had passed away, a burial could be a very public affair. ${ }^{62}$ In many parts of the early-modern world such burials could be contentious. Leisentrit, for one, felt the need to explain Catholic rituals such as bell ringing during funerals, in his Catholic hymn book. Medieval ars moriendi did not contain instructions on burials and only focused on the deathbed. Leisentrit clearly thought burials to be so important that he needed to include them in his parish book. The threat to bury someone in unconsecrated ground, like an animal, did not only have religious connotations but would also impugn the honour of an individual and their family. ${ }^{63}$ As Craig Koslofsky and David Luebke have pointed out in different contexts, burials remained a disputed issue in Germany throughout the sixteenth century because they were interpreted as confessional markers of the deceased and their families. ${ }^{64}$

Some of Leisentrit's recommendations were practical, rather than theologi$\mathrm{cal}$, in nature. When someone was sick and thought that he or she might die, Leisentrit recommended that they should send for a Catholic priest immediately so that he could absolve them and administer the Eucharist. But Leisentrit's recommendations are even more specific, the dying 'richte sein angesicht ernider thu und mache seine augen zu als ehr stürbe oder schlaffen

61 Leisentrit, Pfarbuch 140. For gendered aspects of supernatural beliefs, visible in the phrase 'The Devil and his mother', see Roper L., Oedipus and the Devil. Witchcraft, Sexuality and Religion in Early Modern Europe (London: 1994).

62 Duby G. (ed.), A History of Private Life, vol. 2: Revelations of the Medieval World (Cambridge, MA: 1993) 251.

63 For the importance of honour in judicial proceedings and in Upper Lusatian town statutes, see Schwerhoff G. - Völker M. - Bautzen S., Eide, Statuten und Prozesse. Ein Quellen- und Lesebuch zur Stadtgeschichte von Bautzen 14.-19. Jahrhundert (Bautzen: 2002); Fröde T., Privilegien und Statuten der Oberlausitzer Sechsstädte. Ein Streifzug durch die Organisation des städtischen Lebens in Zittau, Bautzen, Görlitz, Löbau, Kamenz und Lauban in der frühen Neuzeit (Spitzkunnersdorf: 2008).

64 Koslofsky, Reformation of the Dead 115-132; Luebke D.M., Hometown Religion. Regimes of Coexistence in Early Modern Westphalia (Charlottesville - London: 2016) 167-200. 
wolte und sehe oder schawe diese gesellen [des Teufels] gar nichts an' (turn away his face and close his eyes as if he wanted to die or sleep and not look at these accomplices of the Devil). ${ }^{65}$ Whether Leisentrit meant actual demons with these 'accomplices', or the Lutheran friends and family is not made explicit. He recommended that the dying, literally and metaphorically, turn away from the 'ketzerischen rottengeistern' (heretical horde). ${ }^{66}$ Leisentrit advised that 'der Krancke kan soll unnd mag ehr seine ohren mit dem küssen [kissen] zustopffen unnd solche ansichtet unnd verfürer nicht hören' (the sick can, should and may stuff his ears with the pillow so that he does not hear such views and tempters). ${ }^{67}$

This advice is also depicted in the woodcuts in the Pfarbuch. One of the most fascinating illustrations is that of a dying man and a priest who is pointing at a figure resembling Venus or some other heathen idol [Fig. 4.5]. Admonishing the sick to turn away from it, the bed-ridden man turns to the priest instead. He ignores the devil lurking at the bottom of his bed thus complying with Leisentrit's instructions to turn away from any heretical temptations. In another woodcut, the Catholic invalid seems to have died already, his head turned towards the preacher [Fig. 4.6]. A physician is checking his urine (Harnschau) to diagnose the man and make sure he has died, while a Devil attempts to catch the man's eye in vain, as his head is firmly facing the priest who is sitting next to him. ${ }^{68}$ In line with Leisentrit's recommendations, a crucifix has been placed above the dying man to remind him of the prospect of salvation.

Finally, Leisentrit discussed treacherous children who attempt to convert their fathers at the last minute. As Bob Scribner has pointed out, a common trope in Reformation propaganda was the narrative of a son convincing his Catholic father of Lutheranism. ${ }^{69}$ Leisentrit portrayed the same episode rather differently. In Leisentrit's scenario a dying father asks his children to fetch a Catholic priest but when the priest arrives, they lock the door and 'mit kath unnd steinen entfangen hinweg geiagt' (welcomed him with dung and stones, and chased him away). ${ }^{70}$ Here, by closing the door, the children separate their domestic setting from the influence of outsiders, illustrating Leisentrit's concern that the home will be inaccessible to Catholic priests. Indeed, Leisentrit even worried that if the sick person lost his faculties of reason, the heretics

\footnotetext{
65 Leisentrit, Pfarbuch 142.

66 Ibid. 100.

67 Ibid. 142.

68 For the uroscopy, see, for example, Jankrift K.P., Mit Gott und schwarzer Magie. Medizin im Mittelalter (Darmstadt: 2005) 26-28.

69 Scribner R.W., For the Sake of Simple Folk: Popular Propaganda for the German Reformation (Cambridge: 1981) 9 .

$70 \quad$ Leisentrit, Pfarbuch 143.
} 


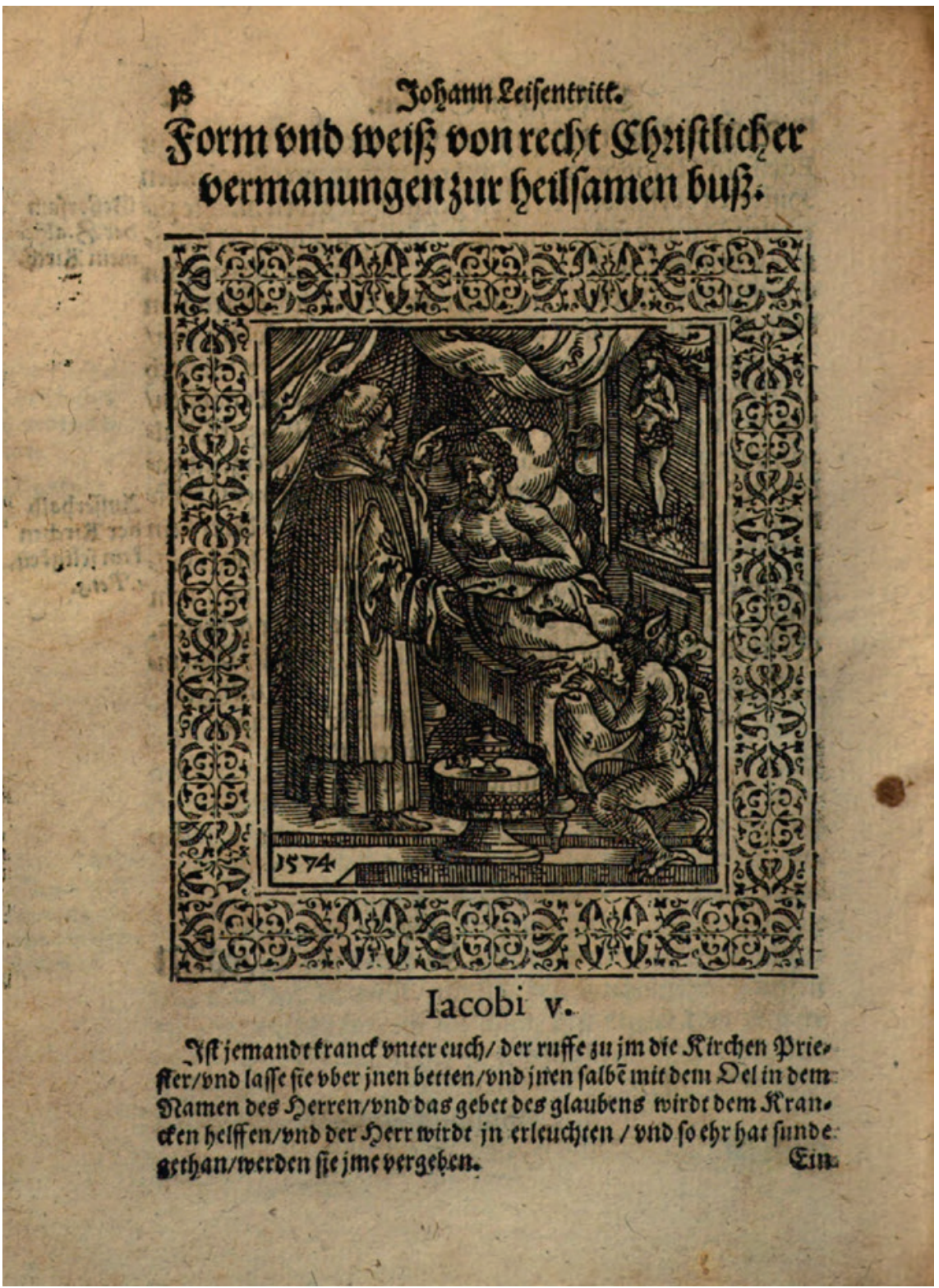

FIGURE 4.5 Unknown artist(s), "Priest with dying man", woodcut illustrations to Johan Leisentrit, Catholisch Pfarbuch oder Form und Weise, wie die catholischen Seelsorger in Ober und Niderlausitz [...] ihre Krancken [...] besüchen, [...] zur [...] Büß, und [...] entpfahung des Heiligen Sacrament des Altars [...] vermanen, [...] in todtes nöten [...] trösten; mit nachfolgung einer Catholischen Protestation wider alle Ketzereyen (Cologne, Maternus Cholinus: 1578), p. 18. Bayerische Staatsbibliothek, Munich, 4 Hom. 534\#Beibd.1 


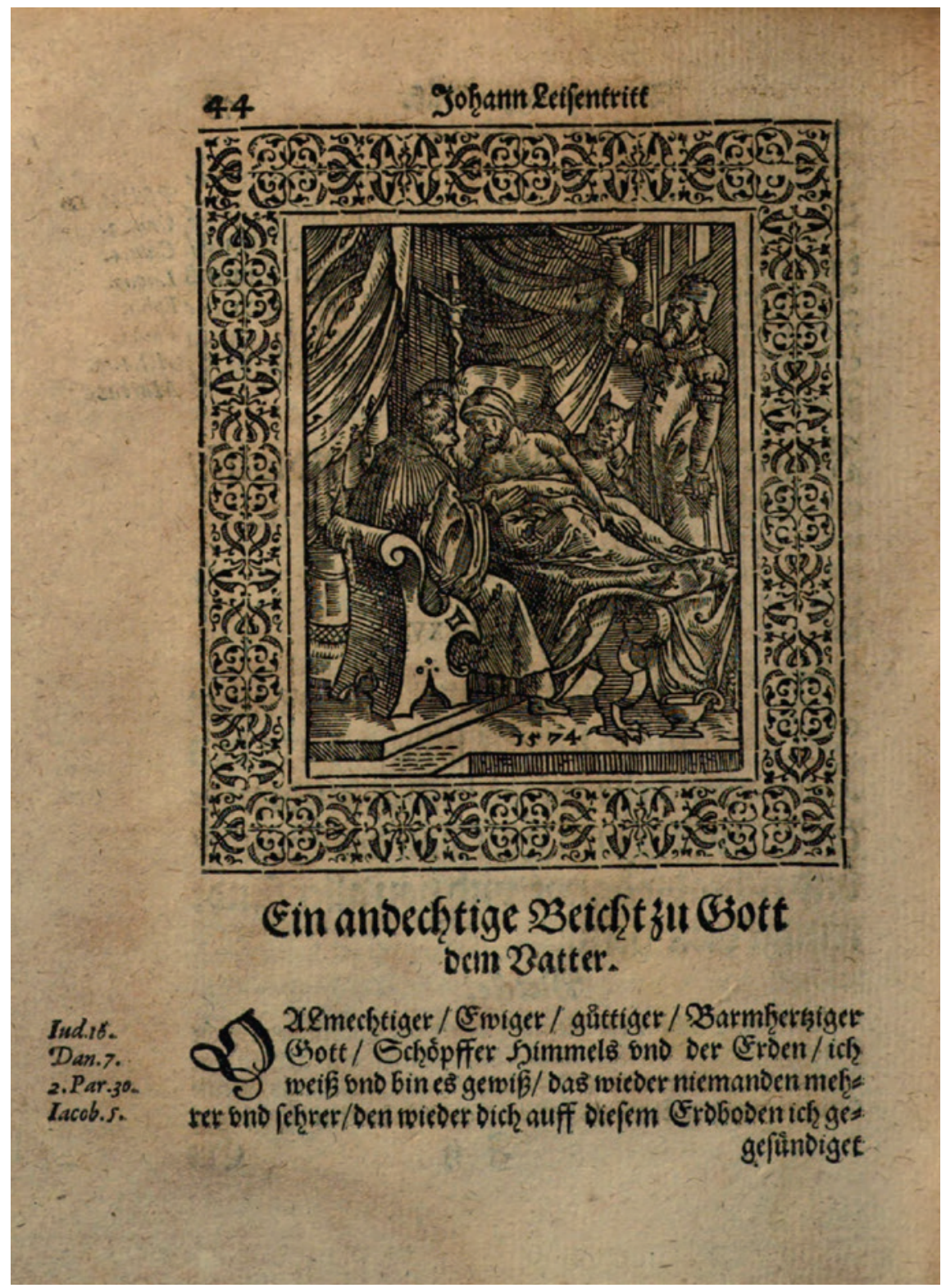

FIGURE 4.6 Unknown artist(s), "Dying man with priest, physician, and Devil", woodcut illustrations to Johan Leisentrit, Catholisch Pfarbuch oder Form und Weise, wie die catholischen Seelsorger in Ober und Niderlausitz [...] ihre Krancken [...] besüchen, $[\ldots]$ zur $[\ldots]$ Büß, und [...] entpfahung des Heiligen Sacrament des Altars [...] vermanen, [...] in todtes nöten [...] trösten; mit nachfolgung einer Catholischen Protestation wider alle Ketzereyen (Cologne, Maternus Cholinus: 1578), p. 44. Bayerische Staatsbibliothek, Munich, 4 Hom. 534\#Beibd.1 ALL IMAGES (4.1-4.6) REPRODUCED WITH KIND PERMISSION OF THE BAYERISCHE STAATSBIBLIOTHEK, MUNICH 
'mit grossem ernst und gewaldt jr vermeinttes Sacrament den sterbenden eingestossen und eingegossen' (push and pour down, with great seriousness and force, their so-called sacrament). ${ }^{71}$ In such circumstances, he wrote, a great 'geschrey und Jubiliren' (shouting and jubilation) would occur and in subsequent sermons the heretics would claim that a Papist in his last moments accepted their sacrament and converted to Lutheranism.

Leisentrit's solution to these problems was quite straightforward; he recommended that any non-Catholic priests should not be admitted into the house. Instead, he suggested that one should always have holy water at hand. ${ }^{72}$ Alec Ryrie's observation that it was 'a truism for pious Christians on all sides [...] that life was a preparation for death' is also applicable to Leisentrit who reminded his flock to lead a pious life to ensure their salvation. ${ }^{73}$ Those who were suffering and weak ought to be reminded of Christ's sacrifice and be consoled by a priest. In line with Catholic doctrine, Leisentrit recommended adding blessed salt to the holy water which should be applied generously to the whole bed chamber, as is depicted in figure 2. According to Leisentrit these actions helped guard against the temptations of Satan who often appeared in 'hesslicher gestalt' (ugly form) to make the sick despair. ${ }^{74}$

The drastic language and repeated emphasis on the difficult position the Catholics found themselves in throughout Leisentrit's works suggest that the dean really perceived his fellow Catholics as persecuted. His works express a genuine concern for his flock. But it was also in Leisentrit's interest to emphasise the difficult position of the Catholics in a printed work that might make its way to other regions of the Holy Roman Empire and Bohemia. ${ }^{75}$ As Leisentrit wanted to ensure continuing royal and imperial protection, focusing on religious conflicts rather than commenting on the many compromises both Lutherans and Catholics made in their daily dealings helped to strengthen the Catholic's position.

\section{Conclusion}

Leisentrit's works demonstrate how difficult it is to separate public and domestic spheres. Although men and women died in their homes, they were

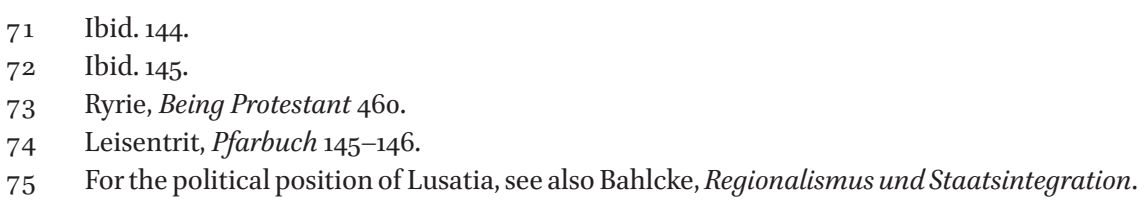


surrounded by relatives and friends and once they had died, the funeral could become a public display of religiosity. As Leisentrit pointed out, the deaths of individuals could later be claimed publicly by the Lutherans or the Catholics. In part because the boundaries between public and private were so fluid, the domestic sphere remained particularly hard to regulate. Leisentrit was therefore willing to be as accommodating as he could in order to ensure that people did not follow heretical beliefs. As Susan Karant-Nunn has pointed out, when it came to dying, Lutherans and Catholics shared many features. ${ }^{76}$ Leisentrit's accommodating approach, together with the porous boundaries between public and private, throws up the question of what, precisely, a confessional, domestic sphere was.

Johann Leisentrit understood that his Catholic flock was exposed to ridicule and threats by a large group of heretics. How much of this persecution was imagined and how much of it was real is impossible to ascertain, but the sources suggest it was not as widespread or as severe as Leisentrit suggested. In Leisentrit's mind, Catholics were vulnerable and weak at the hour of their death, making them easy prey for the Devil and his minions. The private nature of sickness meant that Leisentrit was worried that Catholics, half delirious in their pain, might forsake their faith and risk the salvation of their soul. For Leisentrit, who was willing to compromise with Lutherans but remained a staunch Catholic, this equated to a dangerous victory for the heretics. While Leisentrit emphasised traditional Catholic rituals, such as the holding of a candle or the importance of extreme unction, there are also traces of Lutheranism in his works, most notably his emphasis on solace for the dying. He also hardly mentioned saints and did not refer directly to purgatory which suggests that he was influenced by Lutheranism. A Catholic dying in Upper Lusatia therefore had a difficult choice to make; whether to listen to the consoling words of Johann Leisentrit or to follow the majority of Upper Lusatians into the Lutheran faith.

\section{Bibliography}

Anonymous, Sicherste Streit und Siegs-Kunst im Todteskampff [...]: Aus Herrn Johann Leisentrits [...] Catholischen Pfarrbuch [...] nachgedruckt (s.l., s.n.: after 1648).

Bahlcke J. - Dudeck V. (eds.), Welt - Macht - Geist. Das Haus Habsburg und die Oberlausitz 1526-1635 (Görlitz: 2002).

76 Karant-Nunn, Reformation of Feeling. 
Bahlcke J. (ed.), Die Oberlausitz im frühneuzeitlichen Mitteleuropa. Beziehungen, Strukturen, Prozesse (Leipzig: 2007).

Bahlcke J., Regionalismus und Staatsintegration im Widerstreit. Die Länder der böhmischen Krone im ersten Jahrhundert der Habsburgerherrschaft (1526-16rg) (Munich: 1994).

Becker H. - Fugger D. - Pritzkat J. - Süß K. (eds.), Liturgie im Angesicht des Todes. Reformatorische und katholische Traditionen der Neuzeit, vol. 1: Reformatorische Traditionen (Tübingen - Basel: 2004).

Becker H. - Fugger D. - Pritzkat J. - Süß K. (eds.), Liturgie im Angesicht des Todes. Reformatorische und katholische Traditione der Neuzeit, vol. 2: Katholische Traditionen (Tübingen - Basel: 2004).

Binder T. (ed.), 666 Jahre Sechsstädtebund (Görlitz - Zittau: 2012).

Blaschke K., Beiträge zur Geschichte der Oberlausitz (Görlitz - Zittau: 200o).

Brademann J. - Thies K. (eds.), Liturgisches Handeln als Soziale Praxis. Kirchliche Rituale in der Frühen Neuzeit (Münster: 2014).

Cressy D., Birth, Marriage and Death. Ritual, Religion, and the Life-Cycle in Tudor and Stuart England (Oxford: 1999).

Crust L., The Master E.S. and the 'Ars Moriendi'. A Chapter in the History of Engraving during the XVth Century (Oxford: 1898).

Dannenberg L.-A. - Herrmann M. - Klaffenböck A. (eds.), Böhmen-OberlausitzTschechien. Aspekte einer Nachbarschaft (Görlitz - Zittau: 2006).

David Z.V., Finding the Middle Way. The Utraquists' Liberal Challenge to Rome and Luther (Washington, D.C. - Baltimore - London: 2003).

Dittrich P., Die Meissener Diözese unter der Kirchenpolitik des 16. und 17. Jahrhunderts (Bautzen: 196o).

Duby G. (ed.), A History of Private Life, vol. 2: Revelations of the Medieval World (Cambridge, Mass.: 1993).

Falk F., Die deutschen Sterbebüchlein von der ältesten Zeit des Buchdrucks bis zum Jahre 1520 (Cologne: 1890$)$.

Flaeten J.O. - Rasmussen T. (eds.), Preparing for Death, Remembering the Dead (Göttingen: 2015).

Fröde T., Privilegien und Statuten der Oberlausitzer Sechsstädte. Ein Streifzug durch die Organisation des städtischen Lebens in Zittau, Bautzen, Görlitz, Löbau, Kamenz und Lauban in der frühen Neuzeit (Spitzkunnersdorf: 2008).

Gerblich W., Leisentrit und die Administratur des Bistums Meißen in den Lausitzen (Görlitz: 1931).

Gülden J., Johann Leisentrits Pastoralliturgische Schriften (Leipzig: 1963).

Hahn P., "The Reformation of the Soundscape: Bell ringing in Early Modern Lutheran Germany", German History 33, 4 (2015) 525-545. 
Heimann H.-D. - Neitmann K. - Tresp U. (eds.), Die Nieder-und Oberlausitz-Konturen einer Integrationslandschaft, vol. 2: Frühe Neuzeit (Berlin: 2014).

Heitmeyer E. - Wetzel R., Johann Leisentrit's Geistliche Lieder und Psalmen, 1567. Hymnody of the Counter-Reformation in Germany (Plymouth: 2014).

Heitmeyer E., Das Gesangbuch von Johann Leisentrit 1567. Adaption als Merkmal von Struktur und Genese früher deutscher Gesangbuchlieder (St. Ottilien: 1988).

Jankrift K.P., Mit Gott und schwarzer Magie. Medizin im Mittelalter (Darmstadt: 2005).

Kaplan B.J., Divided by Faith. Religious Conflict and the Practice of Toleration in Early Modern Europe (Cambridge, Mass. - London: 2007).

Karant-Nunn S., The Reformation of Feeling. Shaping the Religious Emotions in Early Modern Germany (Oxford: 2010).

Koslofsky C.M., The Reformation of the Dead. Death and Ritual in Early Modern Germany, c. 1450-1700 (New York: 2000).

Lambert E., "Singing Together and Seeing Differently: Confessional Boundaries in the Illustrated Hymnal", in Dietz F. - Morton A. - Roggen L. - Stronks E. - Vaeck M. van (eds.), Illustrated Religious Texts in the North of Europe, 1500-180o (Farnham: 2014) 257-274.

Leisentrit Johann, Catholisch Pfarbuch oder Form und Weise, wie die catholischen Seelsorger in Ober und Niderlausitz [...] ihre Krancken [...] besüchen [...] (Cologne, Maternus Cholinus: 1590).

Leisentrit Johann, Forma germanico idiomate baptisandi infantes, secundum catholicaeveraeque apostolicae ecclesiae ritum [...]: nebst einer Kirchenordnung (Cologne, Maternus Cholinus: 1585).

Leisentrit Johann, Geistliche Lieder vnd Psalmen, der alten Apostolischer recht vnd warglaubiger Christlicher Kirchen (Bautzen, Hans Wolrab: 1567).

Lipphardt W., Johann Leisentrits Gesangbuch von 1567 (Leipzig: 1964).

Luebke D.M., Hometown Religion. Regimes of Coexistence in Early Modern Westphalia (Charlottesville - London: 2016).

Marshall P. - Walsham A. (eds.), Angels in the Modern World (Cambridge: 2006).

O'Connor M.C., The Art of dying well; the development of the Ars moriendi (New York: 1942).

Pavlickova R.P., "'Unter den Ketzern zu leben und zu sterben ist gar schwerlich und gefehrlich'. Das Sterbebuch des Johann Leisentritt im Kontext der katholischen Sterbebücher des 16. Jahrhunderts", Archiv für Reformationsgeschichte 107 (2016) $193-216$.

Pietsch A. - Stollberg-Rilinger B. (eds.), Konfessionelle Ambiguität. Uneindeutigkeit und Verstellung als religiöse Praxis in der Frühen Neuzeit (Heidelberg: 2013).

Pollman J., "'Hey ho, let the cup go round!' Singing for reformation in the sixteenth century", in Schilling H. - Toth I.G. (eds.), Cultural Exchange in Early Modern Europe, vol. 1 (Cambridge: 2006) 294-316. 
Resch C., Im Angesicht des Todes. Frühe reformatorische Anleitungen zur Seelsorge an Kranken und Sterbenden (Tübingen - Basel: 2006).

Roper L., Oedipus and the Devil. Witchcraft, Sexuality and Religion in Early Modern Europe (London: 1994).

Ryrie A., Being Protestant in Reformation Britain (Oxford: 2013).

Schwerhoff G. - Völker M. - Bautzen S., Eide Statuten und Prozesse. Ein Quellen - und Lesebuch zur Stadtgeschichte von Bautzen 14.-19.Jahrhundert (Bautzen: 2002).

Scribner R.W., For the Sake of Simple Folk: Popular Propaganda for the German Reformation (Cambridge: 1981).

Seifert S., Johann Leisentrit 1527-1586 zum vierhundertsten Todestag (Leipzig: 1987).

Spangenberg Johann, Ein new TrostBuechlin fur die Krancken Vnd Vom Christlichen Ritter (Wittenberg, Georg Rhau: 1548).

Speer C. - Napp Th. (eds.), Musik und Konfessionskulturen in der Oberlausitz der Frühen Neuzeit (Görlitz - Zittau: 2013).

Tankard D., "The reformation of the deathbed in mid-sixteenth-century England", Mortality 8, 3 (2003) 251-267.

Walsham A., "Domesticating the Reformation: Material Culture, Memory, and Confessional Identity in Early Modern England", Renaissance Quarterly 69 (2016) 566-616. 